\title{
Vernacular architecture as heritage
}

\section{La arquitectura vernácula como patrimonio}

VÁZQUEZ-TORRES, María del Rayo, CASTILLO-REYES, Alberto Rosendo, MORALESORTEGA, José Alejandro and MONTERO-URRUSQUIETA, Rubén Ángel

Benemérita Universidad Autónoma de Puebla, Mexico.

ID $1^{\text {st }}$ Author: María del Rayo, Vázquez-Torres / ORC ID: 0000-0002-3509-2684, Researcher ID Thomson: U-85612018, CVU CONACYT ID: 508248

ID $1^{\text {st }}$ Coauthor: Alberto Rosendo, Castillo-Reyes / ORC ID: 0000-0001-6338-2534, Researcher ID Thomson: U-94402018, CVU CONACYT ID: 950754

ID $2^{\text {nd }}$ Coauthor: José Alejandro, Morales-Ortega / ORC ID: 0000-0001-8379-4405, CVU CONACYT ID: 659620

ID $3^{\text {rd }}$ Coauthor: Rubén Ángel, Montero-Urrusquieta / ORC ID: 0000-0001-6325-2238, CVU CONACYT ID: 599097

DOI: $10.35429 / J A D .2020 .12 .4 .1 .10$

Received July 10, 2020; Accepted December 30, 2020

\begin{abstract}
The objective of this research is to recognize vernacular architecture as heritage architecture, a product of the community. The method applied to this research is qualitative in nature, the objective of which is the description of the characteristics of the object of study covering a part of the reality. Qualitative research is inductive, the study is on a small scale and through proximity to empirical reality. The research shows examples that were made through interaction with the inhabitants and as a result of direct observation. The stages of the research were: fieldwork linking access to the site with productive data collection; data analysis in a continuous review that consisted of reducing information, disposition, transformation and obtaining results and verifying them to reach conclusions. The preparation of the report generated a number of approaches, and one of them produced the subject of this work. The contribution of this work is that it aims to place a community rooted in its customs as Is Tochimilco, with an architectural richness that is transformed and even disappearing, because vernacular architecture is considered to be a worthless architecture.
\end{abstract}

Background, Concept, Focus

\begin{abstract}
Resumen
El objetivo de esta investigación es reconocer a la arquitectura vernácula como arquitectura patrimonial, producto de la comunidad. El método aplicado a esta investigación es de carácter cualitativo, cuyo objetivo es la descripción de las características del objeto de estudio que cubra una parte de la realidad. La investigación cualitativa es inductiva, el estudio es en pequeña escala y a través de la proximidad a la realidad empírica. La investigación expone ejemplos que se hicieron a través de la interacción con los habitantes y como resultado de la observación directa. Las etapas de la investigación fueron: el trabajo de campo relacionando el acceso al lugar con la recolección productiva de datos; el análisis de datos en una continua revisión que consistió en reducir la información, disposición, transformación y la obtención de resultados y verificación de estos para llegar a conclusiones. La elaboración del informe generó diversos enfoques, y uno de ellos produjo el tema de este trabajo. La contribución de este trabajo es que pretende colocar a una comunidad arraigada a sus costumbres como es Tochimilco, con una riqueza arquitectónica que se va transformando y hasta desapareciendo, porque se considera a la arquitectura vernácula como una arquitectura sin valor.
\end{abstract}

Antecedentes, El concepto, Enfoque

Citation: VÁZQUEZ-TORRES, María del Rayo, CASTILLO-REYES, Alberto Rosendo, MORALES-ORTEGA, José Alejandro and MONTERO-URRUSQUIETA, Rubén Ángel. Vernacular architecture as heritage. Journal Architecture and Design. 2020. 4-12:1-10.

\footnotetext{
* Correspondence to Author (Email: mrayovt@gmaill.com)

$\dagger$ Researcher contributing as first author.
} 


\section{Introduction}

The current interest in vernacular architecture begins in the sixties of the 20th century and the concepts of natural heritage and cultural heritage are incorporated with an ethnographic approach that favors the recognition of vernacular architecture as heritage. As for the name of vernacular architecture, it is due to Amos Rapoport, who studied vernacular architecture from the point of view of environmental design and gave it a culturalenvironmental approach or what is called ethnographic. Amos Rapoport published in 1969 his book "House, Form and Culture" that provoked a renewed interest in this type of architecture and that in Mexico would provoke the interest of architects to recognize this type of architecture as part of the identity of Mexican architecture.

This architecture has been given different names such as autochthonous, popular or architecture without architects. However, this last name is the one that has generated conflicts to analyze it from the point of view of cultured architecture, since vernacular architecture in many cases lacks a documented temporal identification and a specific author, but in this case the author is the same inhabitant of the house, but his personality was lost in time.

The sections included in this work are: the concepts that intervene in the composition and definition of the term heritage and how vernacular architecture is included as heritage. The work is divided into three subtopics which are: background, concept and approach.

The background section shows the conditions that led to the conservation of objects considered heritage; In the concept subtopic it is shown how the current concept of heritage has been formed and in the focus on vernacular architecture subtopic.

\section{Background}

One of the most important moments in history is the Industrial Revolution, which can be defined as a process that began in the second half of the 18th century, which consisted of economic, social and technological transformation.
With the development of the industry, spaces were required for the industry and to distribute the goods that allowed the emergence of modern architecture ... "In that process the qualities of the new architecture were raised and traditional architecture was devalued, denying them any value functional, social and even aesthetic, radically putting "the new" before "the old" (Rehabimed, 2007, p. 11).

Consequently, vernacular housing is relegated, as it develops outside of European trends; opposed to universality, the dominant classical values and the concept of modernity; this situation prevails in current societies where this architecture is despised.

The most important work in defense of the traditional architecture of the seventeenth century belongs to William Gilpin, English empiricist, who published in 1748, anonymously "A Dialogue on Gardens." From the work of William Gilpin comes the definition of picturesque architecture or vernacular architecture since it was not aligned within the classical or continental historicisms, highlighting characteristics such as the contrast of irregular shapes, textures of the materials of the region that allow integration into the landscape (Maderuelo, 2012).

At the same time, the concept of heritage emerged in the 18th century, when a new philosophy of history was developed, produced by the conflicts between empiricist philosophers and Cartesian conceptions. The Enlightenment favored the renewal of historical science, with contempt for sometimes considered dark and a uniform conception of human nature. The concept of heritage is the product of the appearance of History as an autonomous discipline in the first half of the 19th century. (Hernando, 1995).

Vernacular architecture has been defined as architecture transmitted from one generation to another and is part of the tradition of the communities. This architecture identifies four criteria to characterize it, which are: cultural or socioeconomic, geographical, morphological and architectural or constructive, but its heritage value is discarded. The subject of vernacular architecture does not exist in current architecture teaching, but tourism can lead to its maintenance and even its recovery. (Paz, 2012). 
Vernacular architecture has been called the architecture of the earth; For Estéves and Cuitiño (2020), the earth is an easily accessible material because it is found on the earth's surface and its characteristics are determined by the mineralogical composition of each region, for which there are different procedures to produce products with variable characteristics. It is common that the term "mud" is used to name the clay soil whose components are clay, gravel, sand and silt.

\section{The concept}

Human beings as a product of socialization generated strong emotional ties with the region they inhabit, strengthening their social relationships where each individual needs others to survive. Vara, A. S. (2020), defines this process as the need to care and be cared for, that is, the concept of caring must be understood as the need to protect each other to exist and survive. It is an interdependence that leads to showing affection by safeguarding what is important; care is understood as the set of different activities that contribute to preserving the well-being of people and societies.

The term patrimony comes from a word of Latin origin linked to the idea of property, whose origin is the word "From the Latin patrimonium, property that a person has inherited from his ancestors" or as: "own property acquired by any title".

"For its part, the current vernacular would refer to those assets that are manifested as living heritage, where the vernacular anthropological values of a community that builds, maintains or uses the former are verified. They are works that continue to develop their function - primary or adaptedand that are elaborated, designed or maintained according to the pre-industrial construction tradition or its contemporary evolution "(Pérez Gil, 2018, 5).
Currently, cultural heritage is a collective property of society and for UNESCO, cultural heritage is a social construction of a people and includes the works of its artists, architects, musicians, writers and scholars, they also include anonymous creations, arising from the community that express their creativity that contemplate values that give meaning to their life. Currently, heritage is defined as goods and customs that are transmitted because a value is recognized and they are a collective property. In other words, the concept of heritage as collective inheritance has evolved according to the new conditions of society, recognizing certain (García, 2011).

UNESCO (United Nations Educational, Scientific and Cultural Organization) is an organization created by the World Heritage Committee, which analyzes and evaluates the nominations that countries consider as cultural assets and that they request to be considered as heritage. of humanity; where the representatives of international intergovernmental or nongovernmental institutions with recognition in the subject participate... "The Architectural Heritage is part of the Immovable Material Heritage and is made up of both monumental and unique buildings, as well as those modest and simple that characterize, give identity to the neighborhoods and to the city "(Peñaranda, 2011, p. 15).

In an attempt to unify the criteria for recognizing vernacular architecture, an attempt was made to define it in the Charter of Built Vernacular Heritage (Carta, 2002). In this document the definition of vernacular architecture is expressed in the general considerations to the construction that arises from the community itself; a recognizable local or regional character linked to the territory; consistency of style, shape and appearance. All of this is the product of traditional knowledge that is transmitted informally; product of a need for protection that requires a solution to functional, social and environmental requirements (UCR, 2016). 
The constructed Vernacular Heritage is the product of the relationship between the way of life and tradition; that is, it is the result of the ways in which communities have produced their own habitat. This has occurred within a continuous process, which includes necessary changes and continuous adaptation in response to social and environmental requirements. However, this natural process or this gradual hybridization is threatened throughout the world by the forces of cultural and architectural homogenization. These forces can be controlled and it is the fundamental problem that must be solved by the different communities, as well as by governments, planners and by multidisciplinary groups of specialists. (ICOMOS, 1999).

In recent decades, vernacular architecture has a vulnerable position due to the homogenization of culture and socio-economic globalization, as they face serious problems of obsolescence, internal balance and integration, for which ICOMOS in 1999 created the general considerations to recognize it and its conservation principles. The general considerations include the following:

Vernacular constructions can be recognized by the way of building by the community; its local or regional character linked to the territory; consistency of style, shape and appearance; Traditional wisdom in direct response to functional, social and environmental requirements. Result of the application of traditional construction systems, trades and techniques that allow the community to appreciate and protect the vernacular heritage, the continuity of use and its maintenance.

Governments and authorities must recognize the right of all communities to maintain and protect their traditional way of life. All this through the conservation of the Vernacular Heritage by multidisciplinary groups of experts, recognizing the established cultural identity of a community; as well as cultural values and their traditional character. The built Vernacular Heritage is an integral part of the cultural landscape and must be considered in conservation and development programs. (ICOMOS, 1999).
However, there are currently conflicts between what is mixed heritage or biocultural heritage and the link between cultural heritage and natural heritage. Both heritages are currently facing a conflict with the declarations of protection, since the actions of each are divergent. This occurs because there is no awareness of a clear link between the use of natural resources for the expression of cultural heritage, especially in areas declared as natural reserves and that close to these are spaces or communities that for centuries have been dedicated to the extraction of the raw material required for vernacular architecture, criminalizing the traditional practice and causing the loss of knowledge and knowledge of the use and appropriation of the natural environment. (UCR, 2016).

Vernacular architecture within the economic and progress spheres is not considered heritage since it is considered synonymous with poverty, therefore its protection is not of interest; a situation that has favored their disappearance... "Its habitability has not been enough to express the importance of the Mayan house, which is considered by public policies as a synonym of poverty, an undervaluation that has affected its inhabitants, who in its new generations express: "I live here because I am poor, if I had money I would not live here" (UCR, 2016, p. 114).

It is often thought that vernacular houses are buildings whose materials are unsafe, unhealthy and that are also synonymous with poverty, but the values that these structures possess as a cultural heritage and as a logical response to specific needs are ignored (Peñaranda Orías, 2011).

There is another vision about vernacular architecture that starts from the ICOMOS report, where it was proposed that the heritage declarations be broad to include "monuments" as well as their natural and cultural environment. It was recognized that within countries and communities awareness campaigns should be promoted so that the same communities that generated this heritage, value their construction tradition. 
Supporting this idea, the International Seminar for the Conservation and Restoration of Earth Architecture (SICRAT) was generated, which for more than ten years has carried out case analyzes and workshops with community participation in various traditional towns in northern Mexico and southern states. United (Guerrero B., 2002).

SICRAT is a binational organization whose objective is to make contemporary builders aware of the irreparable damage that rigid and waterproof materials such as cement, steel and plastic substances cause to mud constructions and present alternatives for their intervention. estate. In addition, they promote the recovery of traditional knowledge, the use of traditional construction materials and systems, and teach the inhabitants of the communities to rescue their constructive culture. This causes the users of vernacular dwellings to value and be promoters of their preservation (Guerrero Baca, 2008).

Currently, the preservation tendencies of vernacular architecture do not try to conserve "representative samples" or choreographies that represent the conditions of the past. This is due to the fact that vernacular housing must have a different treatment from that of a historical monument; since housing is a "living" place where spaces are used and adapted to new living conditions. The current idea is to apply methods that make it possible to recover the relationship between architecture and its environment, in order to adapt it to the needs of the users and the specific conditions of each site. But this search is not entirely new. Despite the historical disconnection between what is considered "cultured architecture" and vernacular, at different times in the past architects have recognized a series of qualities in traditional works that served as a source of learning. (Martín Galindo, 2006, p. 104).

An important part of the built heritage is being lost, as well as the wisdom that sustains it; the properties that replace these traditional works affect the quality of life and comfort of its inhabitants, as well as the balance between architecture and its location (Peñaranda, 2011).
For LLull Peñalba (2005), cultural heritage is that manifestation that arises in a society that has been received as a historical heritage, and is part of its identity as a people; where objects become testimonies of the progress of civilization and have the function of modeling its society. The value of the object considers its age and aesthetics as cultural assets with a historical and artistic character, but they coexist with the creations and contributions of the present moment and the socalled intangible legacy. However, the concept of Cultural Heritage is influenced by the perception of the historical destiny of each community, determined by its feelings of national identity, its development potential, the meaning of its social relations, and the way it relates to the environment.

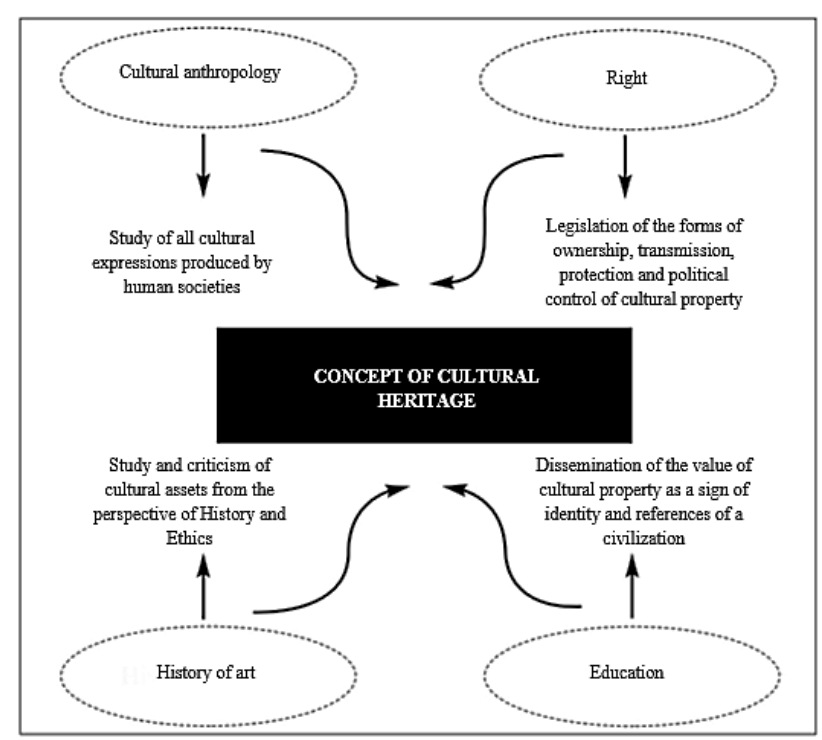

Figure 1 The concept of Cultural Heritage analyzed from an interdisciplinary perspective

Source: Llull Peñalba, $(2005,181)$

\section{Approach}

The vernacular house of central Mexico, preservation of its pre-Hispanic heritage, organization around a patio, in which all activities are carried out abroad. The architectural spatial configuration has a different character depending on the climate and the characteristics of the communities that gives them identity through their colors, materials and architectural elements. In the case of materials, when the raw material emerges from the place, they produce homogeneous sets with minimal variations. 
The character is determined by the physical conditions of the environment such as rain, temperature, humidity, among other aspects. On the other hand, vernacular dwellings are related to local traditions, religious celebrations, food, dances, legends according to international guidelines, they confer heritage value. It is an empirical architecture since its execution is in accordance with its adaptability to the physical environment (Ávila, s.f.).

According to Martín Galindo (2008), it can be seen that tradition allows common cultural manifestations, different values, and allows different expressions to coincide; however, these traditions are imposed by the dominant groups and the dependent groups produce peculiar adaptations called popular. Vernacular architecture keeps its pre-Hispanic characteristics as a result of tradition but has had moments of hybridization where it is transformed or adapted to current needs. That is why the popular term has been put aside to refer to it as "traditional architecture" or "vernacular" ... "the way in which materials, generally extracted from the natural environment, and construction techniques, acquired either by endogenous evolutionary processes or by loans cultural, have served to respond to the physical and social needs of a group, generating architectural models (constructive techniques, spatial designs, and aesthetic results), with original achievements due to the historicalcultural experience and ecological adaptations of each territory "(Martín Galindo, 2006, p. 23).

Vernacular architecture can be understood as a product of tradition, where not only the object or physical part is important; but also the emotional and symbolic part that allows a configuration and distribution in a room. It is common for most of the activities to be done outdoors, in the patio or in the garden as places of conviviality. In groups of houses, the services are common and everyone shares the responsibility for their maintenance. Inside, the furniture is distributed around the room, the kitchen is usually located outside or in a room close to the house, although in rainy seasons it is common to place a bracero near the door for ventilation. The altar and the photographs of the relatives is very important and is placed near the door or in the place that the family considers important.
A population with vernacular architecture is Tochimilco, a town located east of the city of Atlixco, in the state of Puebla, Mexico. It is a population in a risk zone because it is located on the slopes of the active volcano Popocatepetl. The Tochimilco population is that it has the Temple and exFranciscan convent of the Assumption of Our Lady of 1560, it was founded by Fray Diego de Olarte and it is considered a cultural heritage of humanity since 1994. Tochimilco is mestizo and Nahuatl.

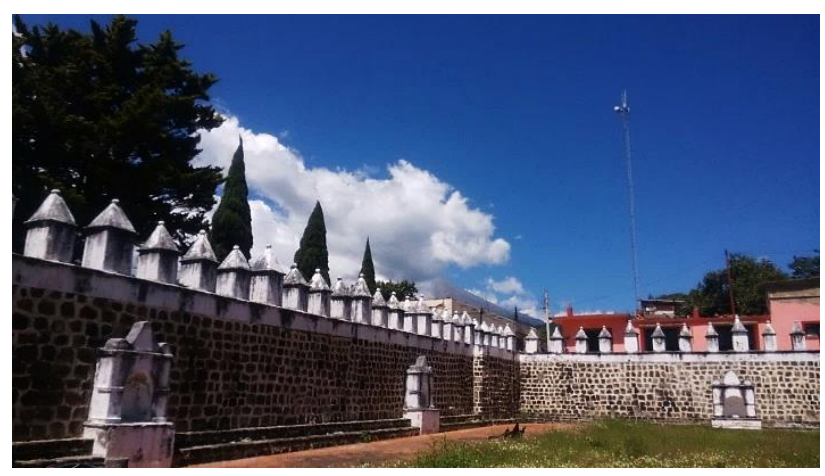

Figure 2 The atrium of the Church of the Assumption of Our Lady is surrounded by a wall finished in battlements or fortress

Source: Vázquez, 2017

The church of the Asunción de Nuestra Señora has a stone cross in the center and its facade is sober and has an open chapel, tower and belfry or wall structure that extends vertically, standing out from the rest of the building, and usually ends in a pinnacle.

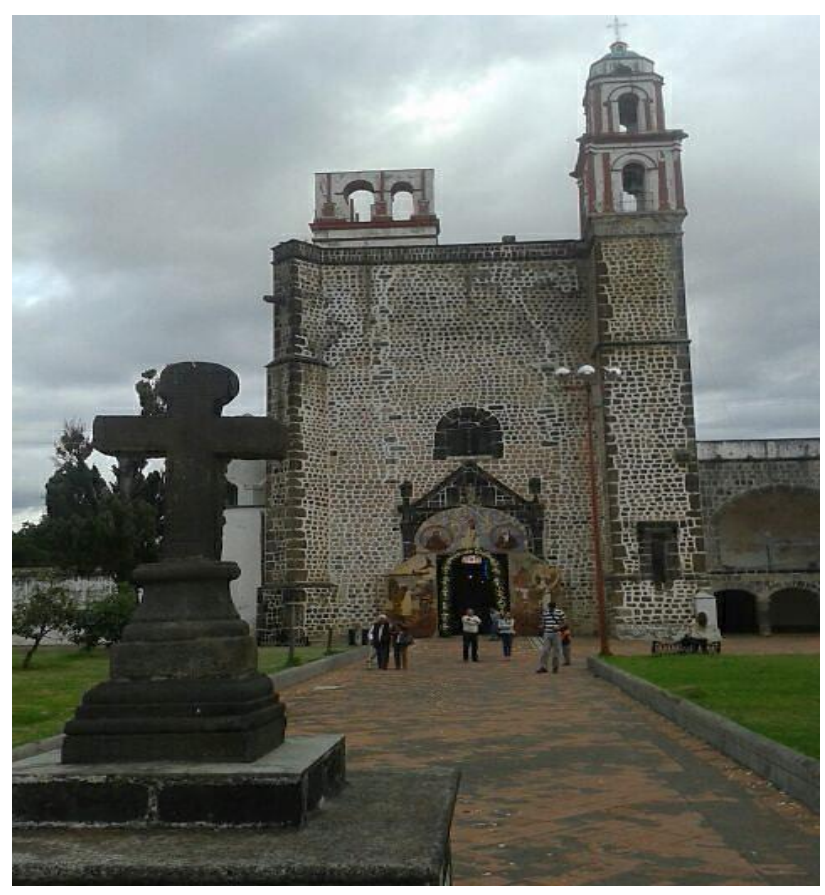

Figure 3 The front of the church of the Assumption of Our Lord

Source: Vázquez, 2017

VÁZQUEZ-TORRES, María del Rayo, CASTILLO-REYES, Alberto Rosendo, MORALES-ORTEGA, José Alejandro and MONTERO-URRUSQUIETA, Rubén Ángel. Vernacular architecture as heritage. Journal Architecture and Design. 2020 
The temple of the Church of the Assumption of Our Lady is of a nave with a flat head and Gothic rib vaults.

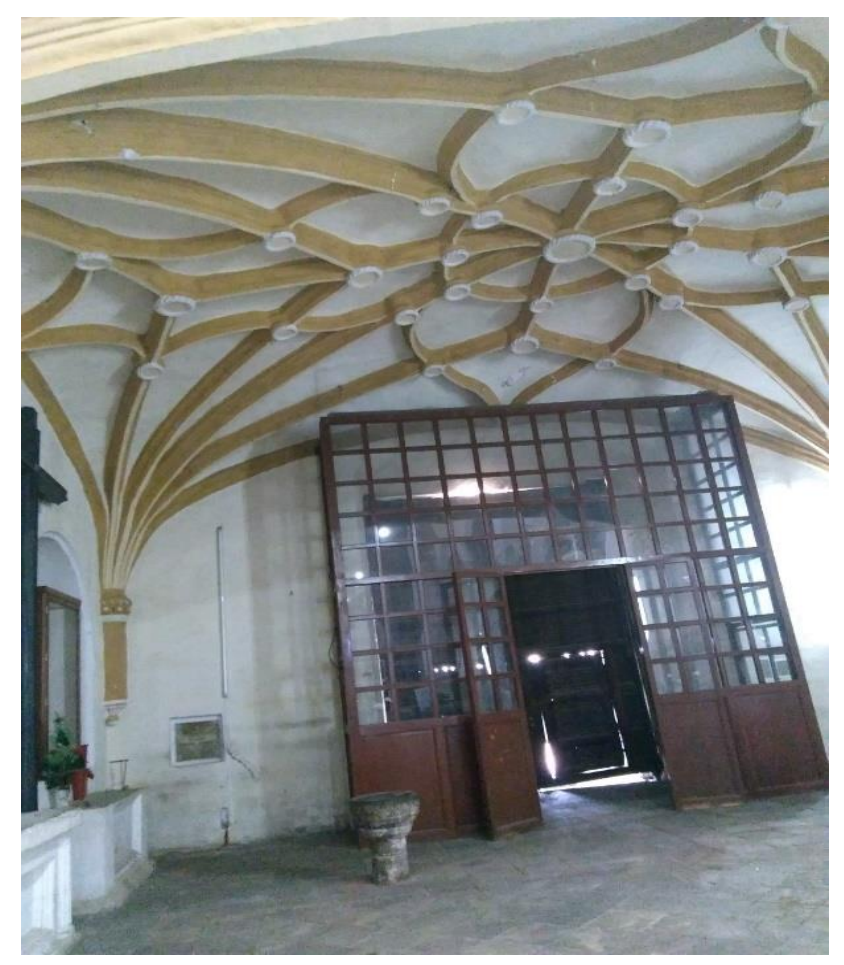

Figure 4 Inside the church where you can see the ribs of the ceiling where the choir is located

Source: Vázquez, 2017

The cloister of the Assumption of Our Lady has columns and lowered arches, a central fountain and remains of wall decorations in red.

After the earthquake of 2017 the church and the former convent of the Assumption of Our Lady.

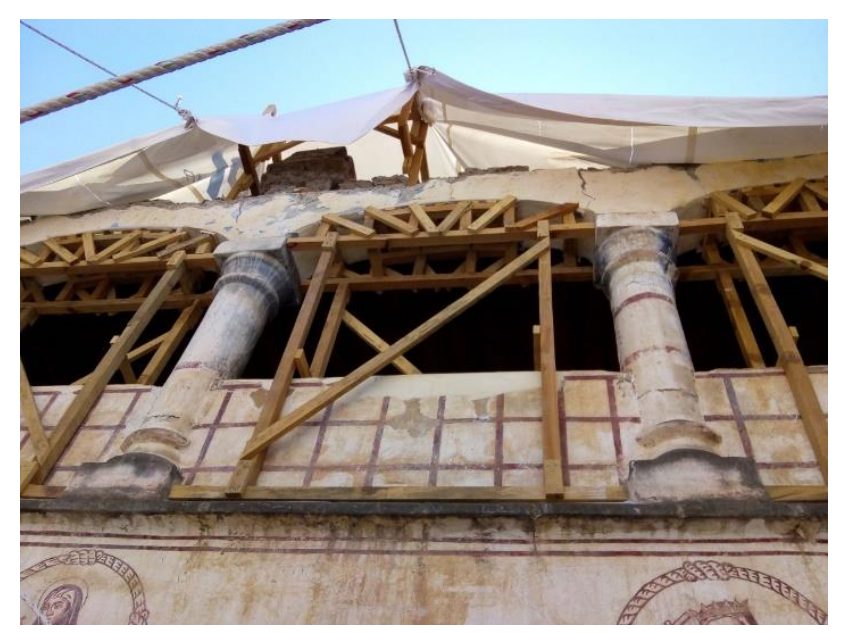

Figure 5 The courtyard of the convent has columns and lowered arches on the ground floor and upper floor. The arches of the upper floor were damaged during the 2017 earthquake and the shoring of the arches is shown in the image

Source: Vázquez, 2017
The open chapel of the Church of the Assumption of Our Lady is above the gate, it has a single arch and there is a pulpit at the base of the tower.

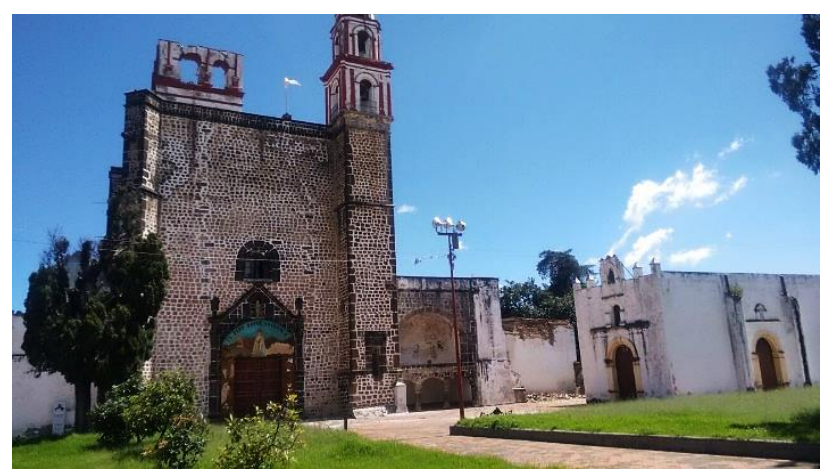

Figure 6 The cover of the church of the Assumption of Our Lady; to the right and next to the tower you can see the open chapel

Source: Vázquez, 2017

Unfortunately, in 1994, Tochimilco was not seen as a heritage complex and vernacular housing was not considered, a situation that caused vernacular architecture to not be protected.

In Tochimilco it is common to see properties where there are several houses belonging to the same family, as is the case in Froylán street, very close to the zócalo.

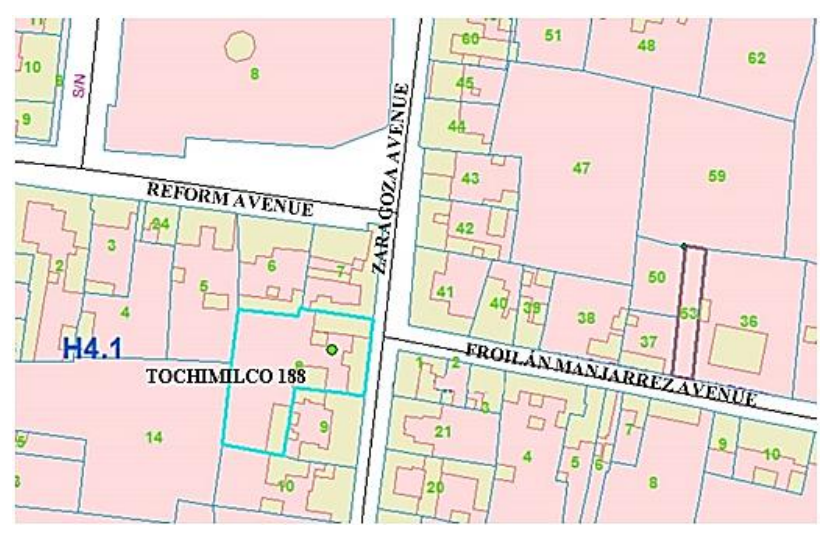

Figure 7 Location of the house on Froylán street Source: Vázquez, 2017

It is the access to the children's homes, with thick adobe walls from the main house. 


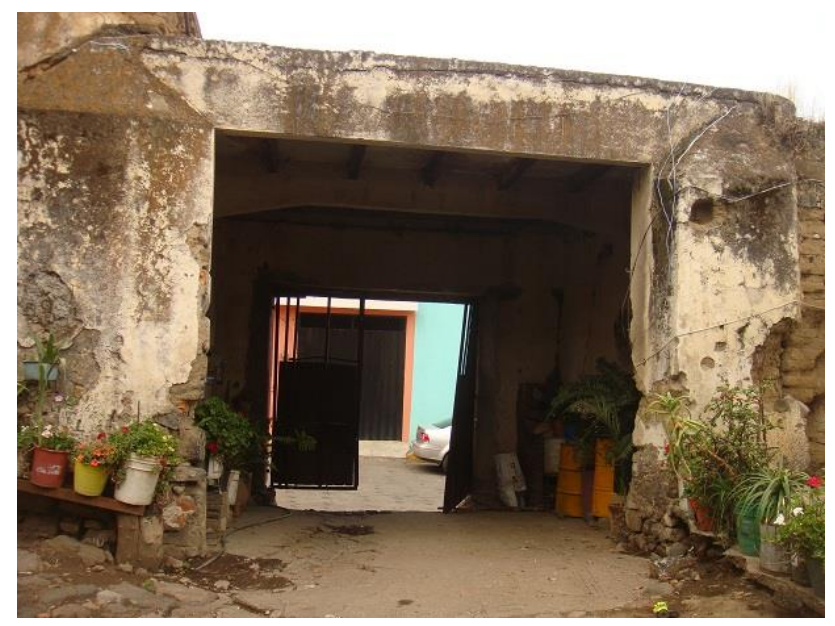

Figure 8 Access to the property, where the roof of beams and brick is observed

Source: Vázquez, 2017

The houses like this that belong to the 18th century have adobe walls covered with wooden beams and red brick, they are constructions that have remained despite the lack of maintenance. However, it is common to see the kitchen or community sanitary services attached to the house.

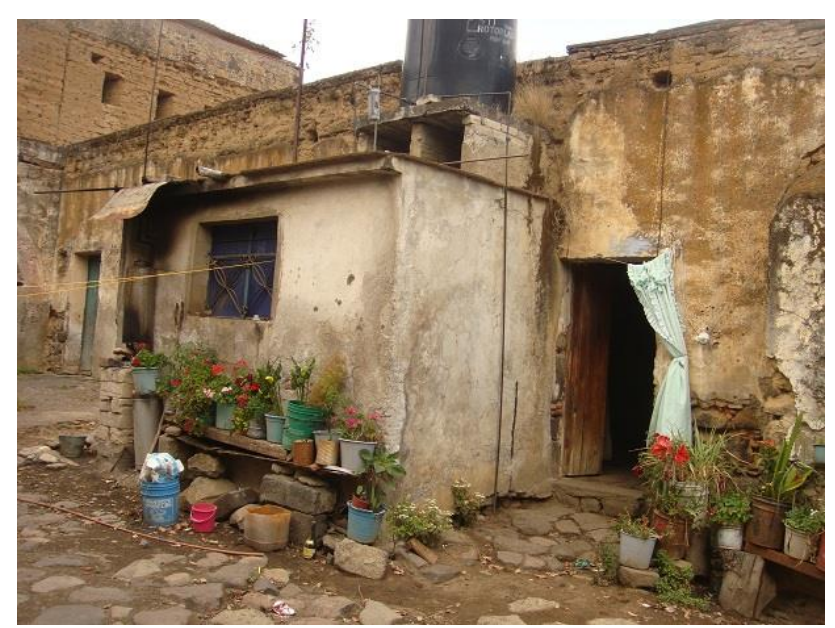

Figure 9 This image shows the adobe construction, divided into parts and each section is inhabited by a family and a room that is used for the toilet is attached to it

Source: Vázquez, 2017

This house was built with blocks, a reinforced concrete structure, and a sheet roof. It is a 2-level construction without interior walls, except for the bathroom. You can see the custom of leaving the pots hanging on the wall of the main entrance; custom that was seen in several houses in the town.

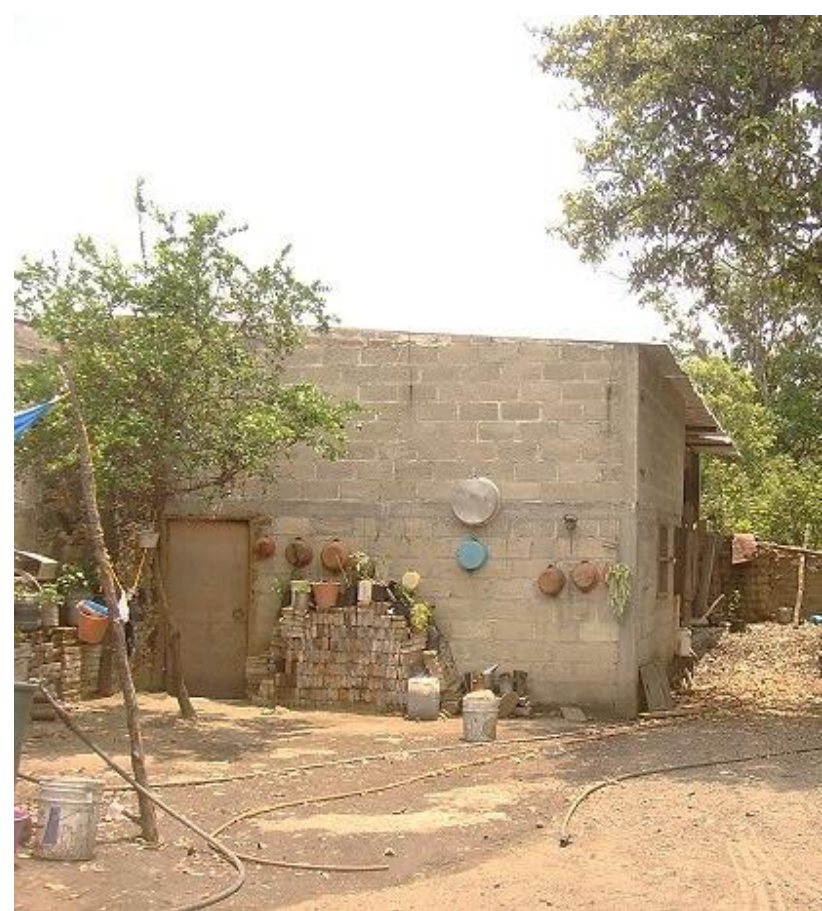

Figure 10 Construction made with a block and two levels and a mezzanine of reinforced concrete slab and a sheet roof

Source: Vázquez, 2017

Within the same land there is a twolevel adobe construction; where each level is a house and a "new" construction of block, brick, reinforced concrete and covered with sheet; which is used as a warehouse.

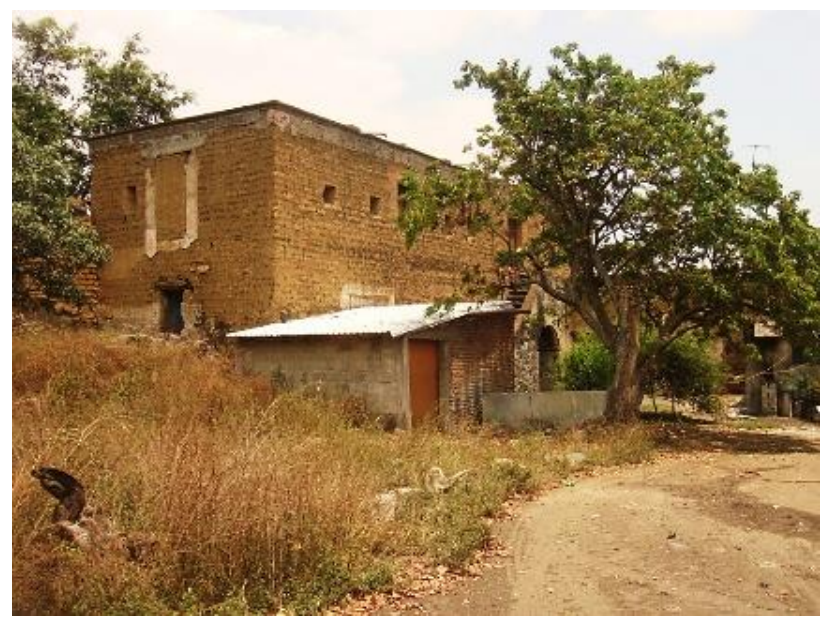

Figure 11 The back construction is of two levels made with adobe and in front is a new house that preserves the traditional characteristics of the vernacular house that they are. Rectangular shape and sloping roof Source: Vázquez, 2017 
As can be seen in the images, the former convent and the church of the Assumption of Our Lady is perfectly cataloged by the INHA (National Institute of Anthropology and History) and by UNESCO (United Nations Educational, Scientific and Scientific Organization). culture). However, vernacular architecture was not protected and much of that wealth has disappeared because it has not been explained or awareness plans have been established for the community to value their buildings.

Coinciding with Pérez Gil (2018), vernacular architecture has been analyzed from the description and classification of types and construction techniques that are directed towards the modes of pure sciences. However, the analysis must also be directed towards humanism and culture as material goods impregnated with cultural values that allow us to know their presence such as constructive, material, technical, type and aesthetic knowledge that allows to base their conservation. Although, vernacular architecture presents difficulties in its study from a historical perspective, because documentary testimony may not exist because it is decontextualized or in the absence of specific constructors of the building without the human factor, it is not possible to speak of culture.

Vernacular architecture in Mexico from its institutions is the most unprotected architecture, although it is recognized as heritage. Therefore, it is necessary to observe vernacular architecture as a cultural asset; that is, as an expression of a certain human community, which is objectified and conserves the essence of the community comprised in its history, customs and traditions. Although its spatial configuration, its forms and its history are important, these elements are criteria of the so-called cultured architecture, both opposite. The values of vernacular architecture lie in its authenticity and it is provided by the same society that produces it. Vernacular architecture is not understood because it is considered emblematic of poverty for using traditional materials or configuring its space in a rudimentary but functional way.

\section{Conclusions}

Consequently, the disappearance and rejection of vernacular housing had their origin in the industrial revolution and its industrialization processes, but this process worsened in the early twentieth century with the modern movement as the hegemonic current. The modern movement provoked the search for new models of living that surpassed the traditional models of making the city.

However, the term heritage also had to evolve in clear opposition to the modern movement and the ethnographic recognition of vernacular architecture that for a long time could not be analyzed. This situation arose from the point of view from the cultured architecture or the architects and not from the anonymous builders.

\section{References}

Ávila, S. (s.f.). La Vivienda Vernácula por, . Obtenido de Arq Vernacula Mexico Vivienda Scribd:

https://es.scribd.com/document/85071942/ArqVernacula-Mexico-Vivienda.

Esteves, M. J., \& Cuitiño, G. (2020). El sistema constructivo de la quincha en zonas rurales del Norte de Mendoza (Argentina). Estoa. Revista de la Facultad de Arquitectura y Urbanismo de la Universidad de Cuenca, 9(17), 153-169.

García, M. P. (2011). El patrimonio cultural. Conceptos básicos, El patrimonio construido, . Zaragoza: Prensas Universitarias, Universidad de Zaragoza.

Guerrero B., L. (2002). Deterioro del patrimonio edificado en adobe . Revista Diseño y Sociedad, No. 13. Otoño, U.A.M.Xochimilco, México. D.F. , 4-11.

Guerrero Baca, L. F. (2008). ICOMOS informe mundial 2006/2007 sobre monumentos y sitios en peligro. MEXICO: La pérdida de la arquitectura de adobe en México. En ICOMOS, HERITAGE AT RISK, Patrimonio en Peligro (págs. 112-114). Alemania: Published by E. Reinhold-Verlag, Altenburg.

Hernando Carrasco, Francisco Javier, (1995) El pensamiento romántico y el arte en España, Cátedra, Madrid, 1995 
ICOMOS. (1999). Carta del patrimonio vernáculo construído, Ratificada por la $12^{a}$ Asamblea General en México, en octubre de 1999. México: Conseil International des monuments et des sites.

Llull Peñalba, J. (21 de Febrero de 2005). Evolución del concepto y de la significación social del patrimonio cultural Escuela Universitaria "Cardenal Cisneros" Universidad de Alcalá. Arte, Individuo y Sociedad 2005, vol. 17 175-204 , 177-206. Obtenido de http:// josue.1lull@www.cardenalcisneros.com

Maderuelo, J. (2012). La mirada pintoresca. Quintana. Revista de Estudos do Departamento de Historia da Arte, 79-90.

Martín Galindo, J. (2006). $L A$ ARQUITECTURA VERNÁCULA, PATRIMONIO DE LA HUMANIDAD. Extremadura, España: DIPUTACIÓN DE BADAJOZ, DEPARTAMENTO DE PUBLICACIONES.

Paz Nuñez, M. (2012). Turismo y patrimonio vernáculo: ¿Estrategia de recuperación sustentable? Universidad de Alcalá. Madrid. España, Paisaje cultural urbano e identitad territorial, $2^{\circ}$ Coloquio Internacional RIGPAC, Florencia 2012 ISBN978-88-548-4841-2 DOIIO.4, 446 y 447.

Peñaranda Orías , L. (2011). CONSERVANDO NUESTRO PATRIMONIO MANUAL PARA LA CONSERVACIÓN, MANUAL PARA LA CONSERVACIÓN DEL PATRIMONIO ARQUITECTÓNICO HABITACIONAL DE SUCRE. Sucre , Bolivia: U.M.M. PATRIMONIO HISTORICO - PRAHS PLAN DE REHABILITACIÓN DE LAS ÁREAS HISTÓRICAS DE SUCRE.

Pérez Gil, J. (2018). Un marco teórico y metodológico para la arquitectura vernácula . CIUDADES, 21 (2018): pp. 01-28 ISSN-E: 2445-3943, 1-28.

Rehabimed. (2007). Método Rehabimed. Arquitectura tradicional mediterránea. Barcelona: Rehabimed.
Torres Zárate, G. (27 de Abril de 2014). Arquitectura vernácula, fundamento en la enseñanza de sustentabilidad. Obtenido de http://sistemamid.com/panel/uploads/biblioteca/ 2014-04-27_01-19-4998077.pd

UCR. (2016). Patrimonio vernáculo en la península de Yucatán:un habitar entre las esferas de lo material e inmaterial. En S. Aurelio, Memoria I Congreso Iberoamericano de patrimonio cultural, Lo material y lo inmaterial en la construcción de nuestra herencia (págs. 112-123). San José: Universidad de Costa Rica, Facultad de Ciencias Sociales, Escuela de Antropología de Costa Rica.

Vara, A. S. (2020). Habita donde pisas. Una aproximación hacia el habitar vernáculo en las cuevas de Granada. Revista de antropología experimental, (20), 5. 